\title{
Declining populations of mountain yellow-legged frogs: a reassessment of the evidence implicating pesticides
}

\author{
J. Marohasy \& J. Abbot \\ School of Medical and Applied Sciences, \\ Central Queensland University, Australia
}

\begin{abstract}
The decline in populations of the Mountain Yellow-legged frogs, Rana sierrae and Rana muscosa, in the Sierra Nevada in California is consistent with a worldwide trend in frog decline that has resulted in nine species extinctions, four of these in Australia. Spray drift from pesticides applied to agricultural crops in California's Central Valley was widely reported as causing the decline, and the claim central to a successful campaign to ban the use of cholinesterase-inhibiting pesticides in California. We reassess the scientific and historical evidence implicating pesticide use in frog decline in California using Hill's Criteria of Causation and show the extent to which the claim is based on correlation, analogy and extrapolation from computer modelling. Critically, concentrations of pesticides in National Parks that have experienced severe decline in frog numbers are orders of magnitude below those shown to produce sub-lethal effects in the laboratory. Of particular concern, output from influential computer modelling work was never validated; no water samples were ever taken to ground truth the calculated pesticide levels.
\end{abstract}

Keywords: causation, pesticide, organochlorine, Rana muscosa, Rana sierra.

\section{Introduction}

Amphibian species, including frogs, toads and salamanders, have experienced severe population declines around the world [1]. At least nine species have become extinct since 1980 and 113 more are possibly extinct [2]. Many theories claim to explain the declines including habitat loss [3] increased UV-B radiation [4], climate change [5], introduced exotic predators [6], disease [7] and pesticide drift 
[8-10]. There have been several particularly prominent cases where pesticides have been implicated and the associated publicity has significantly influenced perceptions about pesticides and their harmful side effects including deformed frogs in Minnesota [11] the feminization of frogs linked to the herbicide Atrazine [12], and spray drift causing frog extinctions in the Sierra Nevada [13].

The claimed linkage between pesticides and frog extinctions has been contentious and emotive. Environmental groups have used the local extinction of frogs in the Sierra Nevada to advocate for the reduction of pesticide use in adjacent agricultural areas and have brought lawsuits in both State and Federal courts, claiming inadequate testing and regulation of pesticides [14]. Claims and counterclaims have made media headlines often with emphasis placed on the reporting of particular pieces of evidence in support of a favoured viewpoint [15].

But how strong is the overall body of evidence implicating the pesticides? In a seminal paper published in 1965, British medical statistician, Austin Hill, outlined nine criteria that can be applied to a body of information to determine whether there is adequate evidence to move from an observed association to a verdict of causation: strength of association; specificity of association; temporality; biological gradient; plausibility; coherence; experimental evidence, consistency and analogy [16]. These criteria now form the basis of modern epidemiological research recognizing they represent logical categories of evidence that can be used to organize information to evaluate a specific hypothesized-cause between two variables [17]. A subset of the criteria has been used to test causality between environmental stressors and effects in aquatic ecosystems [18].

We use Hill's nine criteria to test the popular claim that populations of two species of Mountain Yellow-legged frog, R. muscosa and R. sierrae, have declined as a consequence of the use of cholinesterase-inhibiting pesticides.

\section{Application of Hill's Criteria of Causation}

\subsection{Plausibility}

Organophosphates and carbamate pesticides have been found in the air, rain, and surface waters of the Sierra Nevada and in the tissue of Mountain Yellow-legged frogs [19]. These chemicals can inhibit the proper functioning of the nervous system [20]. Acute poisoning causes death usually by asphyxiation while depressed cholinesterase activity has been associated with reduced physical activity, uncoordinated swimming and depressed growth rates, which are associated with increased vulnerability to predation [21]. Carbamates can also produce developmental malformations in skeletal tissue [22] and musculature of frogs [23]. It is therefore plausible that the presence of the pesticides has caused a decline in frog populations.

\subsection{Experimental evidence}

Experimental evidence enables impacts of a potential stressor on an organism to be studied under carefully controlled conditions. Ideally, evidence is obtained from a progression of more complex experiments from laboratory through to 
microcosm and mesocosm studies. Sublethal concentrations of Carbaryl can influence development [24] and slow swim speed [25]. Sub-lethal concentrations of the organophosphate Chlorpyrifos also negatively impacts on swim speed [26].

In the experiments showing an impact from pesticides on amphibians the dose is typically in the thousands of micrograms per litre [27]. This is in contrast to concentrations of pesticide found in the Sierra Nevada where concentrations are typically in fractions of a microgram per litre, Tables 1 and 2.

Table 1: Concentrations of pesticides found in Sierra Nevada National Parks.

\begin{tabular}{|l|c|}
\hline \multicolumn{1}{|c|}{ Location } & $\begin{array}{c}\text { Concentration } \\
(\mu \mathrm{g} / \mathrm{L})\end{array}$ \\
\hline \multicolumn{2}{|c|}{ Chlorpyrifos } \\
\hline Sixty Lakes (2 sites) [8] & $0.00022,0.00017$ \\
\hline Sixty Lakes (3,231 m) [28] & 0.000195 \\
\hline Tablelands (2 sites) [14] & $0.012,0.00072$ \\
\hline Tablelands (3,322 m) [28] Diazinon & 0.00617 \\
\hline Crescent Meadows (2.042 m) [28] & 0.11815 \\
\hline Moro Creek (823 m) [28] & 0.10425 \\
\hline Lake Tahoe [29] & $0.00018-0.0042$ \\
\hline \multicolumn{2}{|c|}{} \\
\hline Sixty Lakes [8] & 0.0018 \\
\hline Sixty Lakes (3,231 m) [30] & 0.00092 \\
\hline Tablelands (2 sites) [14] & $0.0031,0.0034$ \\
\hline Tablelands (3,322 m) [30] & 0.00323 \\
\hline Crescent Meadows (2.042 m) [30] & 0.06511 \\
\hline Moro Creek (823 m) [30] Malathion & 0.06606 \\
\hline \multicolumn{2}{|c|}{} \\
\hline Sixty Lakes (3,231 m) [30] & $<$ LOD \\
\hline Tablelands (3,322 m) [30] & $<$ LOD \\
\hline Crescent Meadows (2.042 m) [30] & 0.08161 \\
\hline Moro Creek (823 m) [30] & 0.06612 \\
\hline
\end{tabular}

In summary, the experimental evidence is not directly applicable to the situation in the catchment, because pesticide concentrations in the National Parks that have experienced severe decline in frog numbers, are orders of magnitude below those shown to produce even sub-lethal effects in the laboratory.

\subsection{Strength of association}

If Cholinesterase-inhibiting pesticides caused the decline of frogs then areas more exposed to pesticide drift, and thus with higher concentrations of pesticide, would have fewer frogs. This is what Fellers et al. concluded from limited data when comparing pesticide concentrations in water and frogs from two localities at each of two sites in the Sierra Nevada Mountains in 1997 [8]. Their conclusions, 
Table 2: Concentrations of pesticides found in agricultural areas adjacent to National Parks in the Sierra Nevada.

\begin{tabular}{|c|c|}
\hline Location & Concentration $(\mu \mathrm{g} / \mathrm{L})$ \\
\hline \multicolumn{2}{|l|}{ Diazinon } \\
\hline Sacremento River watershed [31] & $0.033-0.08$ \\
\hline Californian rivers [32] & $0.177-2.5$ \\
\hline \multicolumn{2}{|l|}{ Chlorpyrifos } \\
\hline Californian rivers [32] & $0.05-0.35$ \\
\hline \multicolumn{2}{|l|}{ Carbaryl } \\
\hline San Joaquin River at Stevinson [33] & $0.035-0.035$ \\
\hline Merced River [33] & $0.01-0.001$ \\
\hline Orestimba [33] & $0.023-0.004$ \\
\hline San Joaquin River near Crow's Landing [33] & $0.129-0.002$ \\
\hline San Joaquin River near Patterson [33] & $0.049-0.004$ \\
\hline San Joaquin River at Maze Road Bridge near Modesto [33] & $0.185-0.002$ \\
\hline Stanislaus River [33] & $0.044-0.001$ \\
\hline San Joaquin River Near Vernalis [33] & $0.114-0.002$ \\
\hline San Joaquin River at Stevinson [33] & $0.014-0.002$ \\
\hline San Joaquin River near Crow's Landing [33] & $0.028-0.003$ \\
\hline San Joaquin River near Patterson [33] & $0.011-0.003$ \\
\hline Del Puerto Creek [33] & $0.12-0.002$ \\
\hline Tuolumne River [33] & $0.02-0.002$ \\
\hline San Joaquin River at Maze Road Bridge near Modesto [33] & $0.015-0.004$ \\
\hline Stanislaus River [33] & $0.014-0.002$ \\
\hline San Joaquin River near Vernalis [33] & $0.0070-0.03$ \\
\hline \multicolumn{2}{|l|}{ Diazinon } \\
\hline San Joaquin River at Stevinson [33] & $0.014-0.004$ \\
\hline Merced River [33] & $0.004-0.002$ \\
\hline San Joaquin River near Patterson [33] & $0.067-0.001$ \\
\hline Del Puerto Creek [33] & $0.082-0.003$ \\
\hline Tuolumne River [33] & $0.01-0.002$ \\
\hline San Joaquin River at Maze Road Bridge near Modesto [33] & $0.029-0.002$ \\
\hline Stanislaus River [33] & $0.004-0.001$ \\
\hline San Joaquin River near Vernalis [33] & $0.024-0.002$ \\
\hline \multicolumn{2}{|l|}{ Malathion } \\
\hline San Joaquin River at Stevinson [33] & $0.027-0.027$ \\
\hline Salt Slough [33] & $0.012-0.004$ \\
\hline Mud Slough [33] & $0.027-0.027$ \\
\hline Merced River [33] & $0.004-0.003$ \\
\hline Orestimba [33] & $0.081-0.004$ \\
\hline San Joaquin River near Crow's Landing [33] & $0.016-0.005$ \\
\hline San Joaquin River near Patterson [33] & $0.088-0.003$ \\
\hline Del Puerto Creek [33] & $0.033-0.002$ \\
\hline Tuolumne River [33] & $0.004-0.002$ \\
\hline San Joaquin River at Maze Road Bridge near Modesto [33] & $0.014-0.002$ \\
\hline Stanislaus River [33] & $0.006-0.004$ \\
\hline San Joaquin River near Vernalis [33] & $0.007-0.004$ \\
\hline
\end{tabular}


suggest an association between exposure to pesticide drift and the presence or absence of the frogs.

One of the sites, Sixty Lakes Basin in Kings Canyon National Park, had large, apparently healthy populations of frogs, while a nearby site, Tablelands in Sequoia National Park, which was exposed directly to prevailing winds from agricultural regions, had no frogs. Furthermore, despite the eradication of trout from the lakes at the Tablelands site, and repeated attempts at reintroducing Mountain Yellowlegged frogs to this site, there was no breeding population.

The last twenty frogs reintroduced in 1994 or 1995 that could be found were collected from the Tablelands in 1997, and pesticide concentrations in both frog tissue and the water were measured and compared with frog and water samples from two localities at Sixty Lakes. The organophosphate Chlorpyrifos was found in water at all four localities with the highest concentrations at one of the Tablelands site. Diazinon was found in similar concentrations at the two Tablelands sites, and at much lower concentrations at one of the Sixty Lakes sites. Diazinon was not detected in any frog tissue samples and Chlorpyrifos was present above the analytical detection limit only at one sample from Sixty Lakes. Fellers et al. [8] concluded organophosphate insecticides were observed in surface waters at higher concentration at the Tablelands than at Sixty Lakes, indicating atmospheric inputs from up-wind agricultural areas. No attempt, however, was made to relate the measurable presence of these pesticides to experimental work which would have showed that the levels found in the National Park were orders of magnitude lower than found to have any effect on frog growth and/or behaviour (see Section 2.2, and Tables 1 and 2).

Davidson [10] also concluded that the presence of the pesticide must be causing harm using a computer model that simulated pesticide use in California from 1974 to 1991 to explain the decline of five Californian amphibian species including Mountain Yellow-legged frogs. Davidson [10] emphasized the association between population decline and cholinesterase-inhibiting pesticides. But in all of this hypothesising and modelling, the concentrations of the pesticide found in the water bodies, even at the higher concentrations, was orders of magnitude less than anything ever found to affect amphibians in laboratory experiments.

\subsection{Biological gradient}

There is a general gradient of decreasing concentrations of organophosphate pesticide in air, rainwater, surface water and snow in the Sierra Nevada with distance and elevation from the Central Valley [29, 30, 34].

Davidson and Knapp [35] using generalized additive models found a statistically significant relationship between total upwind pesticide-use and the occurrence of Mountain Yellow-legged frogs and that small differences in the amount of upwind pesticide-use had a large effect on the probability of frog occurrence indicating the presence of a biological gradient.

Davidson [10] and Davidson and Knapp [35] claim their work is based on an eco-toxicological approach and his findings are often cited as evidence for an impact from spray drift on frogs [36], but there are significant limitations which invalidate the results. 
The percentage of upwind agricultural land was used as a proxy for the intensity of wind-borne agrochemicals that frog habitat sites experienced and this proxy designated the "dose" parameter. The work of Davidson [10] and Davidson and Knapp [35] is based on output from established research programs on pesticide drift in California where there has been full reporting of agricultural pesticide use since 1990 and an extensive database exists with the California Department of Pesticide Regulation [37, 38].

Davidson and Knapp [35] combined this information with an extensive survey of 6,831 water bodies covering an area that including all of Sequoia, Kings Canyon, and Yosemite National Parks, as well as a portion of the John Muir Wilderness (located north of Kings Canyon), a region encompassed approximately $7373 \mathrm{~km}^{2}$ of rugged mountainous terrain. But no water samples were ever taken to ground-truth the pesticide levels calculated by the computer model.

Various assumptions were made about spray drift to generate the hypothetical dose gradient. But spray drift is a complex phenomenon where equipment design and application parameters, spray physical properties and formulation, and meteorological conditions interact and influence the pesticide losses [39]. Many factors influence pesticide atmospheric emissions during application, including technical and environmental features [40].

Once in the atmosphere, pesticides are dispersed and transported by the wind. [40]. Spatial distribution is influenced by both physical and chemical properties, as well as environmental factors such as meteorological conditions [41] and sophisticated analytical techniques are required to measure atmospheric concentrations of pesticides [42]. As a consequence, the composition of a pesticide mixture transported to a remote location could be very different to calculated averaged downwind concentrations of applied components. Degradation rates for different pesticides also vary significantly, once they are taken up in a lake or river. There will also be variability in exposed water bodies, such as depth [43, 44], factors influencing dilution and mixing [45] rates of outflow [46] and the nature of sediments which may adsorb chemical contaminants [47] which will influence concentrations of deposited pesticides to which frogs are exposed.

These considerations make it difficult to relate the amount of any particular pesticide or class of pesticide applied within a given time period to concentrations expected to be present in a particular water body, located perhaps hundreds of kilometres from the initial application point. Thus it is necessary to validate the significance of the modelled pesticide dosage with physical measurements of pesticide concentrations before any conclusions can reasonably be drawn regarding a spatially relevant dose-response relationship.

\subsection{Consistency of association}

According to computer modelling by Davidson [10], cholinesterase-inhibiting pesticides are consistently associated with the decline in populations of Californian amphibians and this modelling has been used as persuasive evidence for an association with population decline in the Mountain Yellow-legged frog including in litigation against the continued registration and use of these pesticides in California [48]. However, the model output was never validated and so it is 
unknown how the virtual "dose" relates to the dose of the chemical stressor experienced by the Mountain Yellow-legged frogs and other species of amphibian in the Sierra Nevada.

\subsection{Temporality}

There is no simple temporal relationship between the decline in populations of the Mountain Yellow-legged frogs in the Sierra Nevada and the use of cholinesteraseinhibiting pesticides or pesticides more generally. The decline in frog populations was noted in the early 1900s and at that time was associated with the introduction of trout into the once fishless lakes of the Sierra Nevada with trout observed to feed on the tadpoles [49].

The widespread use of pesticides began in the 1940s. Environmental concerns with organochlorines led to their replacement with organophosphates and carbamates in the early 1970s. Data from the Pesticide Action Network Database [38] indicates the use of Carbaryl, Chlorpyrifos and Aldicarb peaked in 1996 and has since declined. The use of Diazinon, Malathion and Endosulfan has shown a general reduction since 1991 [38]. There has been no recovery in populations of Mountain Yellow-legged frogs commensurate with the reduction in pesticide use. Rather, there is some evidence that frog populations continue to show general decline [50].

\subsection{Coherence}

In order for an association to have coherence, the cause and effect interpretation of the data should not be seriously in conflict with generally known facts. That the general decline in populations of Mountain Yellow-legged frogs preceded the use of cholinesterase-inhibiting suggests that the association lacks coherence. Furthermore, the claim that there is an association is based primarily on virtual science, which is output from computer models that has not been validated against real world data.

\subsection{Analogy}

Contamination of the environment by pesticides, particularly from spray drift, is an emotive issue and has been the focus of environmental campaigning in the US since the New York Times serialized Rachel Carson's book Silent Spring in June 1962. Many people would like to see all pesticides banned and particularly pesticides applied in such a way that there is spray drift. Given the potential for pesticide spray drift from the Central Valley to the Sierra Nevada, given frogs are sensitive to chemical toxins, by analogy it could be concluded that pesticides will be negatively impacting frog populations in the Sierra Nevada.

\subsection{Specificity of association}

It is common in ecological risk assessments to find that more than one factor is contributing to population decline. For example, it has been established that 
exposure to sub-lethal concentrations of pesticide can predispose frogs to predation [51]. Studies of population decline in Mountain Yellow-legged frogs conclude that factors additional to cholinesterase-inhibiting pesticides are likely to be affecting frog populations, but it is beyond the scope of this paper to undertake a review of the many factors, suffice to mention that introduced disease is emerging as the most credible theory for recent declines in frog populations in the Sierra Nevada [52].

\section{Discussion and conclusions}

The decline in populations of Mountain Yellow-legged frogs in the Sierra Nevada is consistent with a worldwide trend. Ostensibly to reverse this trend in the Sierra Nevada and avoid the extinction of Mountain Yellow-legged frogs, environment groups have campaigned to ban the use of cholinesterase-inhibiting pesticides in the Central Valley of California.

This review has shown, however, that the claim that cholinesterase-inhibiting pesticides has caused population decline is tenuous and based primarily on analogy and virtual data from computer modelling. Nevertheless, the belief that cholinesterase-inhibiting pesticides have caused the extinction of frog populations in California is now well entrenched globally.

After applying Hill's criteria and evaluating the evidence for causality, it can be concluded that there is no conclusive evidence to indicate cholinesteraseinhibiting pesticides as a cause for the decline in populations of Mountain Yellowlegged frogs.

The conservation of amphibian populations worldwide is not aided when researchers draw misleading analogies because of at best tenuous and at worst fabricated evidence from California. It is common in the scientific literature concerning amphibian decline, for researchers to speculate about the possible synergistic effects of sub-lethal dosages of pesticides on frogs and tadpoles. In order to test these speculative claims there is a need for experimental work to be undertaken at chemical concentrations equivalent to those found in natural water bodies.

\section{Acknowledgement}

This work was funded by the B. Macfie Family Foundation.

\section{References}

[1] Houlahan, J.E., Findlay, C.S., Schmidt, B.R., et al., Quantitative evidence for global amphibian population declines, Nature, 404, pp. 752-7581, 2000.

[2] Stuart, S.N., Chanson, J.S., Cox, N.A., et al., Status and trends of amphibian declines and extinctions worldwide, Science, 306, pp. 17831786, 2004. 
[3] Cushman, S.A., Effects of habitat loss and fragmentation on amphibians, A review and prospectus, Biological Conservation, 128(2), pp. 231-240, 2006.

[4] Blaustein, A.R. \& Belden, L.K., Amphibian defences against ultraviolet-B radiation, Evolution \& Development, 5, pp. 89-97, 2003.

[5] Carey, C., \& Alexander M.A. Climate change and amphibian declines, is there a link? Diversity and Distributions, 9(2), pp. 111-121, 2003.

[6] Kats, L.B. \& Ferrer, R.P., Alien predators and amphibian declines, review of two decades of science and the transition to conservation, Diversity and Distributions, 9(2), pp. 99-110, 2003.

[7] Morgan J.A.T., Vredenburg V.T., et al. Population genetics of the frogkilling fungus Batrachochytrium dendrobatidis, PNAS, 104(34), pp. 1384513850, 2007.

[8] Fellers G.M. \& McConnell L.L., et al. Pesticides in mountain yellow-legged frogs (Rana muscosa) from the Sierra Nevada Mountains of California, USA, Environmental Toxicology and Chemistry, 23(9), pp. 2170-2177, 2004.

[9] Davidson C., Shaffer H.B., \& Jennings M.R., Spatial Tests of the Pesticide Drift, Habitat Destruction, UV-B, and Climate-Change Hypotheses for California Amphibian Declines, Conservation Biology 16(6), pp. 15881601, 2002.

[10] Davidson, C., Declining downwind, Amphibian population declines in California and historical pesticide use, Ecological Applications 14(6), pp. 1892-1902, 2004.

[11] Fort, D.J., Rogers, R.L., et al., Progress toward identifying causes of maldevelopment induced in Xenopus by pond water and sediment extracts from Minnesota, USA, Environmental Toxicology \& Chemistry 18(10), pp. 2316-2324, 1999.

[12] Hayes, T.B., Collins, A., Lee M, et al., Hermaphroditic demasculinized frogs after exposure to the herbicide atrazine at low ecologically relevant doses, PNAS, 99, pp. 5476-5480, 2002.

[13] Sparling, D.W., Fellers G.M., \& McConnell, L.L., Pesticides and amphibian population declines in California USA, Environmental Toxicology \& Chemistry, 20(7), pp. 1591-1595, 2001.

[14] PTCN (Pesticide and Toxic Chemical News). Settlement reached in redlegged frog case, p. 13, 2006.

[15] Avery, D.. Rachel Carson Syndrome, Jumping to Pesticide Conclusions in the Global Frog Crisis, Hudson Institute, Washington, USA, 2007.

[16] Hill, A.B., The environment and disease, association or causation? Proceedings of the Royal Society of Medicine, 58, pp. 295-300, 1965.

[17] Thygesen, L.C., Andersen, G.S., \& Andersen, H., A philosophical analysis of the Hill criteria. Journal of Epidemiology and Community Health, 59(6), pp. 512-516, 2005.

[18] Adams, S.M., Establishing causality between environmental stressors and effects on aquatic ecosystems, Human \& Ecological Risk Assessment, 9, pp. 17-35, 2003. 
[19] Fellers, G.M., Green, D.E., \& Longcore J.E., Oral chytridiomycosis in the mountain yellow-legged frog (Rana muscosa), Copeia pp. 945-953, 2001.

[20] Balasundaram K., Selvarajan V.R., Inhibition of acetylcholinesterase in the central nervous system of Rana tigrina by an organophosphate, Journal of Biochemical Toxicology, 5, pp. 65-66, 1990.

[21] Berrill, M., Coulson, D., \& McGillivary, L., et al., Toxicity of endosulfan to aquatic stages of anuran amphibians, Environmental Toxicology and Chemistry, 17, pp. 1738-1744, 1998.

[22] Alvarez, R., Honrubia M.P., \& Herraez M.P. 1995. Skeletal malformations induced by the insecticides ZZ-Aphox and Folidol during larval development of Rana perezi. Archive of Environmental Contamination and Toxicology, 28, pp. 349-356, 1995.

[23] Rzehak K, Maryanska-Nadachowska, A. \& Jordan, M, The effect of Karbatox 75, a carbaryl insecticide, upon the development of tadpoles of Rana temporaria and Xenopus laevis. Folia Biologica (Kraków), 25, pp. 391-399, 1977.

[24] Boone MD, Bridges CM, Effects of carbaryl on green frog (Rana clamitans) tadpoles, Timing of exposure versus multiple exposures. Environmental Toxicology \& Chemistry, 22(11), pp. 2695-2702, 2003.

[25] Punzo, F., Effects of insecticide (Carbaryl) exposure on activity and swimming performance of tadpoles of the Rio Grande Leopard Frog, Rana berlandieri (Anura, Ranidae), Texas Journal of Science, 57(3), pp. 263272, 2005.

[26] Widder, P.D., \& Bidwell, J.R., Tadpole size, cholinesterase activity, and swim speed in four frog species after exposure to sub-lethal concentrations of chlorpyrifos, Aquatic Toxicology, 88(1), pp. 9-18, 2008.

[27] Sparling, D.W, \& Fellers, G., Comparative toxicity of chlorpyrifos, diazinon, malathion and their oxon derivatives to larval Rana boylii, Environmental Pollution, 147(3), pp. 535-539, 2007.

[28] LeNoir J.S., Aston L., Data S., et al. Environmental exposures to agrochemicals in the Sierra Nevada Mountain Range, Analysis of Environmental Endocrine Disruptors, 747, pp. 53-72, 2000.

[29] McConnell, LL, Le Noir L.S., Datta, S., et al. Wet deposition of current-use pesticides in the Sierra Nevada Mountain Range, California, USA, Environmental Toxicology \& Chemistry, 17, pp. 1908-1916, 1998.

[30] LeNoir JS, McConnell LL, Fellers GM, et al., Summertime transport of current-use pesticides from California's Central Valley to the Sierra Nevada Mountain Range, USA. Environmental Toxicology \& Chemistry, 18(12), pp. 2715-2722, 1999.

[31] Guo, L., Kelley, K., Goh, K.S., et al. Evaluation of Sources and Loading of Pesticides to the Sacramento River, California, USA, during a Storm Event of Winter 2005. Environmental Toxicology \& Chemistry, 26(11), pp. 22742281, 2007.

[32] Spurlock, F., Analysis of diazinon and chlorpyrifos surface water monitoring and acute toxicity bioassay data, 1991-2001. http,//www.cdpr.ca.gov/docs/emon/pubs/ehapreps/eh0101.pdf 
[33] Domagalski, J.L., \& Munday, C., Evaluation of Diazinon and Chlorpyrifos Concentrations and Loads, and other Pesticide Concentrations, at Selected Sites in the San Joaquin Valley, California, April to August, 2001, US Geological Survey, Water-Resources Investigations Report 03-4088. http,//pubs.usgs.gov/wri/wri034088/pdf/wri03_4088.pdf

[34] Zabik, J.N. \& Seiber, J.N., Atmospheric transport of organophosphate pesticides from California's Central Valley to the Sierra Nevada mountains. Journal of Environmental Quality, 22(2), pp. 80-90, 1993.

[35] Davidson, C. \& Knapp, R.A., Multiple stressors and amphibian declines, Dual impacts of pesticides and fish on yellow-legged frogs. Ecological Applications, 17(2), pp. 587-597, 2007.

[36] Matthews, K.R. \& Preisler, H.K., Site fidelity of the declining amphibian Rana sierrae (Sierra Nevada yellow-legged frog), Canadian Journal of Fish \& Aquatic Science, 67, pp. 243-255, 2010.

[37] CDPR (California Department of Pesticide Regulation). 1999. Summary of Pesticide Use Report Data, 1998. Available at http.//www.cdpr.ca.gov

[38] PAN (Pesticide Action Network Pesticide Database), 2008. Available at http,//www.pesticideinfo.org/

[39] Gil, Y., \& Sinfort, C., Emission of pesticides to the air during sprayer application, A bibliographic review. Atmospheric Environment, 39(28), pp. 5183-5193, 2005.

[40] Van Pul, W.A.J., Bidleman, T.F., \& Brorstrom-Lunden, E., Atmospheric transport and deposition of pesticides, an assessment of current knowledge. Water, Air, and Soil Pollution, 115, pp. 245-256, 1999.

[41] Hapeman, C.J., McConnell L.L., \& Rice, C.P., Current United States Department of Agriculture - Agricultural research service research on understanding agrochemical fate and transport to prevent and mitigate adverse environmental impacts. Pest Management Science, 59, pp. 681-690, 2003.

[42] Briand, O., Millet, M., Bertrand, F., et al. Assessing the transfer of pesticides to the atmosphere during and after application. Development of a multi-residue method using adsorption on tenax and thermal desorptionGC/MS, Analytical and Bioanalytical Chemistry, 374(5), pp. 848-857, 2002.

[43] Pope, K.L., \& Matthews, K.R., Movement Ecology and Seasonal Distribution of Mountain Yellow-Legged Frogs, Rana muscosa, in a HighElevation Sierra Nevada Basin, Copeia, pp. 787-793, 2001.

[44] Knapp, R.A., Matthews, K.R., Preisler, H.K., et al., Developing probabilistic models to predict amphibian site occupancy in a patchy landscape, Ecological Applications 13(4), pp. 1069-1082, 2003.

[45] Nikolaidis, V.S. \& Schnoor, J.L., Assessment of Episodic Acidification in Sierra-Nevada, California. Aquatic Science, 53(4), pp. 330-345, 1991.

[46] Berg, N., Osterhuber, R., Bergman, J., Rain-Induced Outflow from Deep Snowpacks in the Central Sierra-Nevada, California. Hydrological Science Journal, 36, 611-662, 1991. 
[47] Weston, D.P., You J., \& Lydy M.J., Distribution and toxicity of sedimentassociated pesticides in agriculture-dominated water bodies of California's Central Valley, Environmental Science \& Technology, 38(10), pp. 27522759, 2004.

[48] N.D. Cal. (US District Court for the Northern District of California). Center for Biological Diversity versus Environmental Protection Agency. No. C 02-01580 JSW. Decided September 19, 2005.

[49] Drost, C.A. \& Fellers, G.M., Collapse of a regional frog fauna in the Yosemite area of the California Sierra Nevada, USA, Conservation Biology, 10(2), pp. 414-425, 1996.

[50] Vredenburg, V.T., Bingham R., Knapp R., et al., Concordant molecular and phenotypic data delineate new taxonomy and conservation priorities for the endangered mountain yellow-legged frog, Journal of Zoology, 271(4), pp. 361-374, 2007.

[51] Bridges, C.M., Tadpole swimming performance and activity affected by acute exposure to sub-lethal levels of carbaryl, Archives of Environment Contamination \& Toxicology, 16, pp. 1935-1939, 1997.

[52] Rachowicz, L.J., Knapp, R.A., Morgan, J.A.T., et al. Emerging infectious disease as a proximate cause of amphibian mass mortality, Ecology, 87(7), pp. 1671-1683, 2006. 